\title{
Disability vs Spatial Planning and Landscaping - Selected Examples
}

\author{
Paweł Szumigała \\ e-mail: pawelszumigala@wp.pl, pawelsz@up.poznan.pl
}

Piotr Urbański

e-mail:ktzpurb@up.poznan.pl,ktzpurb@wp.pl

Department of Green Space and Landscape Architecture, Poznań University of Life Sciences

\begin{abstract}
The article presents issues related to designing recreational and green areas and spatial planning of public areas in the context of physical disability. It gives exemplary proposals of public space development and spatial solutions for people with disabilities. It also discusses issues related to the designing and construction of selected items of landscape architecture for physically disabled people, which were created as part of the education of landscape architects.
\end{abstract}

Keywords: physical disability, architectural barriers, public space planning, development of green areas.

\section{Introduction}

The range and manner of satisfying disabled people's needs, especially in terms of their motor activity, is one of basic tasks to do when developing people's surroundings. It chiefly concerns the development of public space. Ubiquitous architectural barriers still cause problems to elderly people, mothers with small children and above all, to disabled people. However, in recent years there has been noticeable progress in this matter. The number of architectural barriers has decreased and at present public investments such as parks, green spaces, urban spaces - squares, streets and new buildings are being equipped with facilities for disabled people. The main regulation which describes the issue of accessibility of buildings to disabled people is Article 5, Paragraph 1, No. 4 of the Building Code Act of 7 July 1994. According to the Building Code (i.e. Official Journal 2013, Pos. 1490 and Official Journal 2014, Pos. 40, 768, 822), a building and its facilities should be designed and constructed according to the expected time of their use so that they will meet technical and constructional requirements specified in applicable regulations, (...) ensuring that public facilities and multi-family residential buildings are adjusted to the needs of disabled people, especially those on wheelchairs. Detailed regulations specifying the adjustment of buildings to disabled people's needs can be found in the Regulation on the technical requirements and location of buildings issued by the Minister of Infrastructure on 12 April 2002 (Official Journal No. 75, Pos. 690 of 2002 with later alterations). Thanks to the novelisation of the Building Code we can see progress in this matter. Also, increasing social awareness and users' expectations of public space with adequately high spatial standards resulted in a greater number of facilities and areas equipped with items for physically disabled people. These are chiefly items of street furniture and landscape architecture as well as mechanical devices located at places with different altitude levels and at entrances to buildings. If there are no disabled facilities in a building and adjacent area, it gives grounds for claiming subsidies to liquidate architectural, technological and transport barriers. It is in agreement with the Regulation of the Minister of Labour and Social Policy of 25 June 2002, specifying the type of tasks for a county which can be financed from the State Fund for Rehabilitation of Disabled Persons (Official Journal No. 96, Pos. 861 of 2002 with later alterations). Thus, each design task must meet the requirements concerning the knowledge of designing, spatial planning and landscaping. Designing is characterised by the fact that it concerns a particular place, which is a component of the 
environment in its broad social, cultural, industrial, natural and utilitarian sense. Apart from statutory requirements, branch standards and regulations which must be abided by in the process of designing public space, it is also important to maintain the aforementioned high spatial standards in facilities. Developing awareness of the issue and designing skills are also part of the educational process involved in training architects, landscapers and planners. When students are being educated, they need to design essential facilities, such as car parks, walkways, bicycle paths, benches, lamp posts, waste containers, stairs and wheelchair ramps for physically disabled people. Students have to design these elements in a specific spatial situation, using adequate materials and they have to present technical solutions and visualisations of the designed element of spatial development in a specific, assigned or selected spatial situation.

\section{Material and methods}

In order to illustrate the aforementioned issue in more detail we analysed four selected examples of student projects done as part of practice in Designing Landscape Architecture Facilities, which is a subject at the Department of Green Space and Landscape Architecture at the Poznań University of Life Sciences. The projects are related with an essential element of landscape architecture, i.e. the wheelchair ramp. Legal aspects concerning the design of such facilities are specified in the aforementioned Regulation of the Minister of Infrastructure of 12 April 2002, which lists the technical requirements concerning buildings and their location and provides details of the technical parameters that a design of a wheelchair ramp must meet. Thus, the table below lists the maximum gradient of ramps for pedestrian and wheelchair traffic depending on the ramp height.

Table 1. The ramp surface gradient Nachylenie powierzchni pochylni
No.
Gradient
Outdoors
Indoors
1.
up to $0.15 \mathrm{~m}$
$15 \%$
$15 \%$
2.
up to $0.5 \mathrm{~m}$
$8 \%$
$10 \%$
3.
over $0.5 \mathrm{~m}$ *
$6 \%$
$8 \%$

Source: Regulation concerning technical requirements and location of buildings issued by the Minister of Infrastructure on 12 April 2002.

Ramps for pedestrian and wheelchair traffic which are longer than $9 \mathrm{~m}$ should be divided into shorter segments by means of landings with a minimum length of $1.4 \mathrm{~m}$. Planes for traffic on disabled ramps should be at least $1.2 \mathrm{~m}$ wide. They should be equipped with curbs, which must be at least $0.07 \mathrm{~m}$ high, and handrails on both sides. The space between the handrails should not be narrower than $1 \mathrm{~m}$ and wider than $1.1 \mathrm{~m}$. Banisters or walls adjacent to the wheelchair ramp should be fitted with handrails on both sides. The handrails should be placed at 0.75 and $0.9 \mathrm{~m}$ above the plane of traffic. The horizontal plane of traffic at the beginning and at the end of the ramp should be at least $1.5 \mathrm{~m}$. The area of the landing next to the wheelchair ramp should be at least $1.5 \times 1.5 \mathrm{~m}$ outside the opening field of the entrance door. When both handrails are extended $30 \mathrm{~cm}$ beyond the ramp ends, it makes entering and exiting the ramp much easier. Usually the handrail extension is semi-circularly curved, thus connecting the upper and lower handrail. Apart from technical conditions the utilitarian and scenic aspects should also be taken into consideration when developing public space. This aspect of landscaping and designing elements of landscape architecture will have fundamental influence on the aesthetics of green space as well as urban space and landscape. The selection and quality of materials as well as colours and shape of forms give space its individual character. 


\section{Results}

The examples of ramps and accompanying elements show design solutions with more dynamic forms and colours. In these cases the ramps and other elements of development are treated both as utilitarian and artistic forms, which should enrich, vary and diversify both urban landscape and green space. Figures 1, 2 and 3 show the views and projection of the suggested spatial and colour solutions for the ramp and stairs.
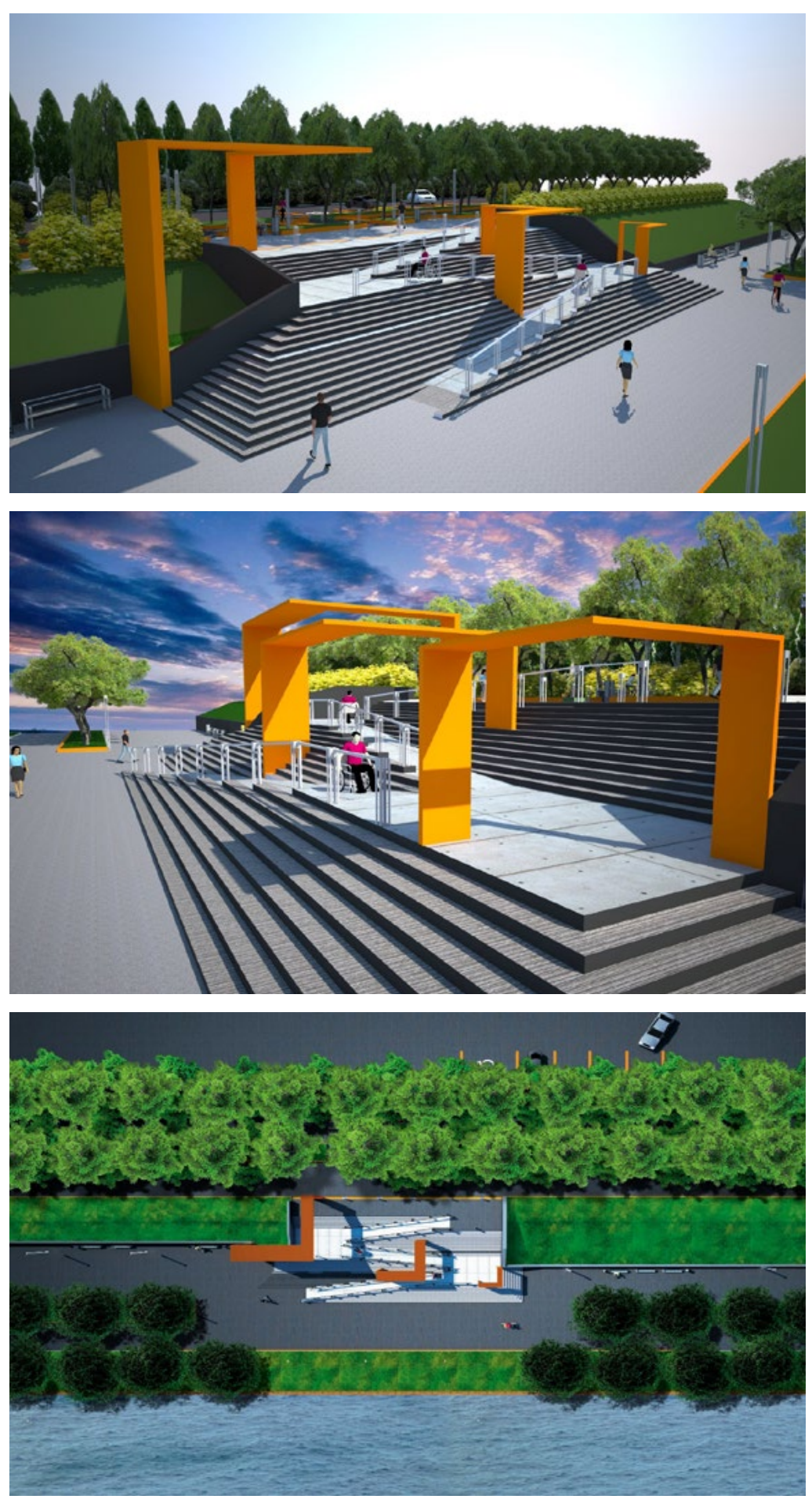

Fig. 1. A ramp - view 1, source: Bogalecki M. A designing exercise in a course in Designing Landscape Architecture Facilities 2, Department of Green Space and Landscape Architecture, Poznań University of Life Sciences, 2013.

Pochylnia - widok 1, źródło: Bogalecki M. Ćwiczenie projektowe z przedmiotu Projektowanie Obiektów Architektury Krajobrazu 2, KTZiAK UP Poznań, 2013.

Fig. 2. A ramp - view 2, source: Bogalecki M. A designing exercise in a course in Designing Landscape Architecture Facilities 2, Department of Green Space and Landscape Architecture, Poznań University of Life Sciences, 2013.

Pochylnia - widok 2, źródło: Bogalecki M. Ćwiczenie projektowe z przedmiotu Projektowanie Obiektów Architektury Krajobrazu 2, KTZiAK UP Poznań, 2013.

Fig. 3. A ramp projection - top view. Another colour variant of decorative canopies. Source: Bogalecki M. A designing exercise in a course in Designing Landscape Architecture Facilities 2, Department of Green Space and Landscape Architecture, Poznań University of Life Sciences, 2013.

Pochylnia - rzut, widok z góry. Inny wariant kolorystyczny ozdobnych zadaszeń. źródło: Bogalecki M. Ćwiczenie projektowe z przedmiotu Projektowanie Obiektów Architektury Krajobrazu 2, KTZiAK UP Poznań. 


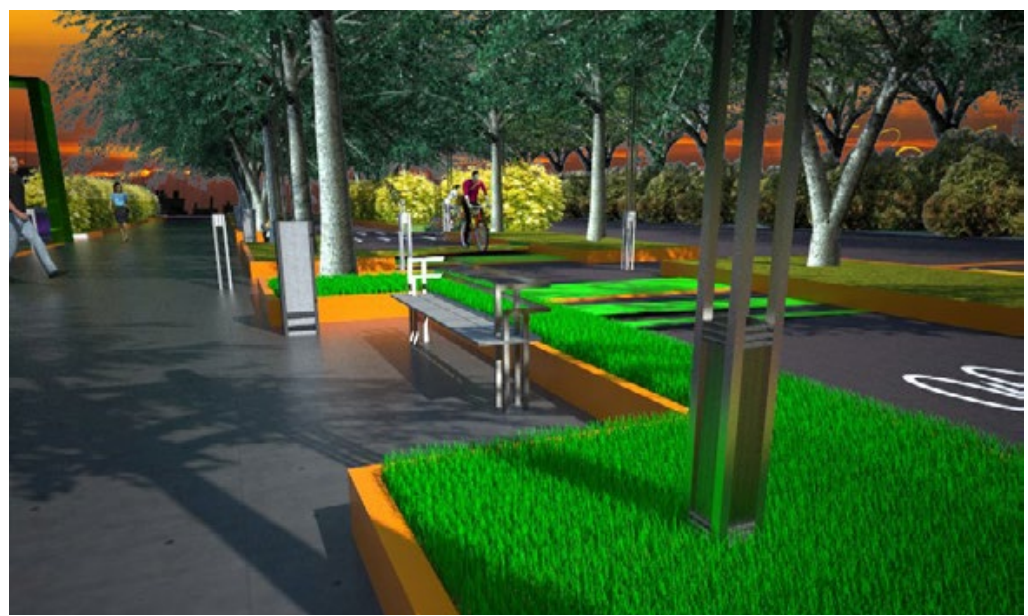

Fig. 4. A view of a bay with a seat. A designing exercise in a course in Designing Landscape Architecture Facilities 2, Department of Green Space and Landscape Architecture, Poznań University of Life Sciences, 2013.

Widok na zatoczkę przy siedzisku. źródło: Bogalecki M. Ćwiczenie projektowe z przedmiotu Projektowanie Obiektów Architektury Krajobrazu 2, KTZiAK UP Poznań, 2013.

They are a connection of pedestrian and bicycle traffic, located on the scarp crown and foot, running along the Warta River in Szelągowski Park in Poznań. Figure 4 shows the accompanying elements, such as seats and a pedestrian walkway adjacent to the ramp. In the design we can see a big bay in front of a bench, which facilitates using the bench. It provides space for a wheelchair, which can be left next to the bench. The bay is big and deep enough to manoeuvre and park a wheelchair without obstructing pedestrian traffic. It is also noteworthy that a dustbin is placed at the edge of the bay rather than right next to the bench. This ensures an adequate buffer zone between the bench and dustbin and it enables people moving on wheelchairs to use the dustbin freely. Providing a sufficiently large usable area in the zone of public space equipment and development is a very important requirement in designing and execution of spatial plans with due consideration of physically disabled people's needs. For scenic and aesthetic reasons, it is important that elements of landscape architecture should be designed and executed so that they will become inherent elements of the existing surroundings. As far as this issue is concerned, it is very difficult to make a ramp an inherent part of its surroundings due to its big size, especially the length, which depends on the difference between the levels it connects. For example, when the difference between the levels is $2.0 \mathrm{~m}$, the minimum ramp length required by regulations is $39.30 \mathrm{~m}$. Thus, although the aforementioned difference between the levels is not very big under natural conditions, a facility of a considerable length must be designed. The problem becomes much more serious when there is an even bigger difference between the levels, e.g. about $7 \mathrm{~m}$ (Figure 5). Then the ramp must be about $150 \mathrm{~m}$ in length. In this case, the ramp consists of 14 sloping segments with a maximum length of $9 \mathrm{~m}$ and 15 horizontal segments with a minimum length of $1.4-1.5 \mathrm{~m}$. In order to meet this requirement ramps should be designed so as to meet the necessary conditions of use required by law and to cause as little spatial disturbance to the landscape as possible, as can be seen in Figures 5 and 6 .

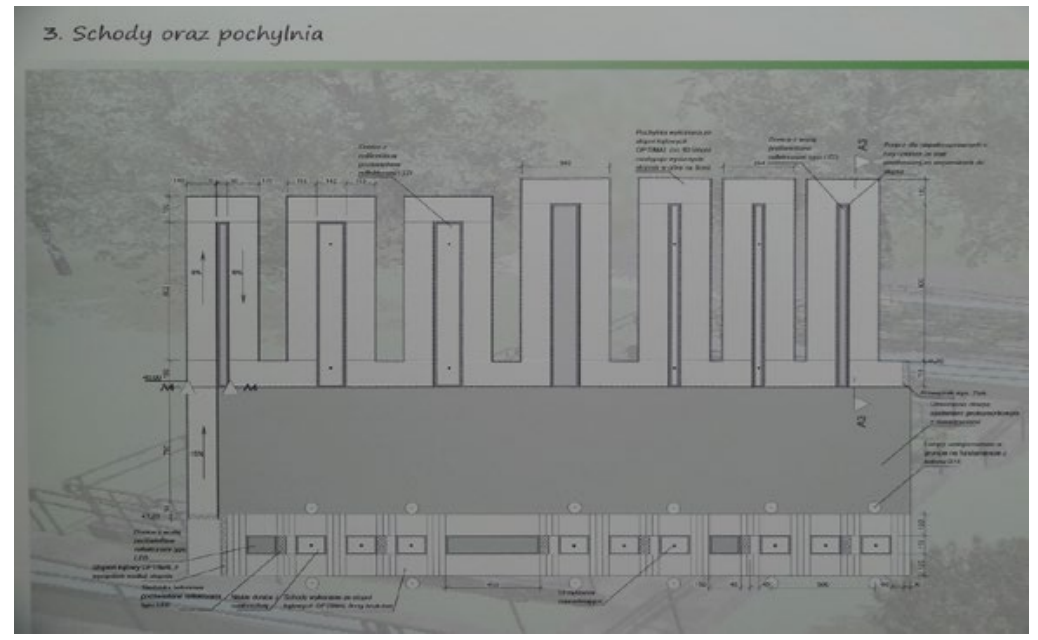

Fig. 5. A projection of a ramp with an altitude difference of about $7 \mathrm{~m}$. Source: Olszewska A. A designing exercise in a course in Designing Landscape Architecture Facilities 2, Department of Green Space and Landscape Architecture, Poznań University of Life Sciences, 2013.

Rzut pochylni przy różnicy wysokości terenu wynoszącej ok. 7 m. źródło: Olszewska A. Ćwiczenie projektowe z przedmiotu Projektowanie Obiektów Architektury Krajobrazu 2, KTZiAK UP Poznań, 2013. 

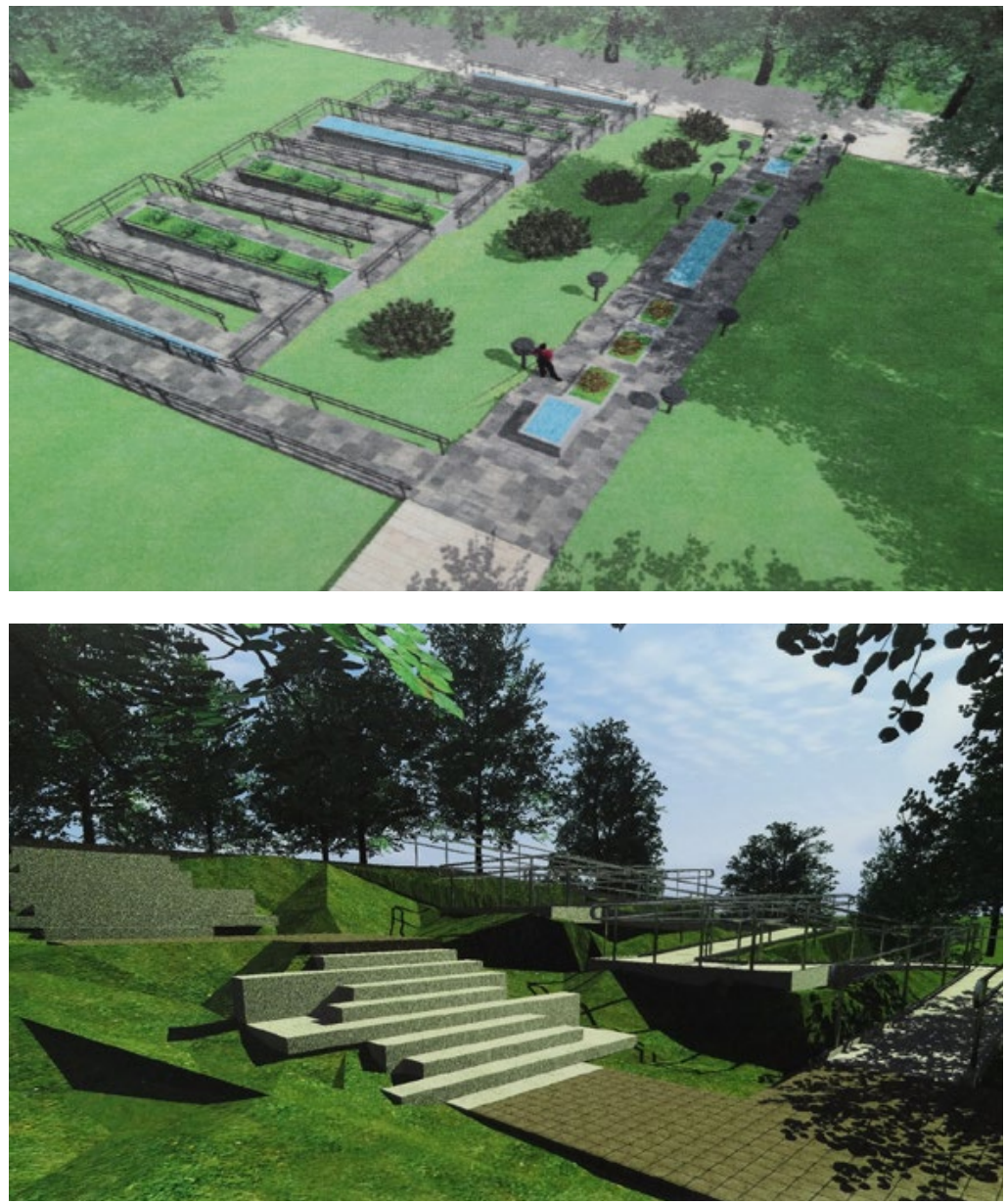

Fig. 6. A view of the ramp with an altitude difference of about $7 \mathrm{~m}$. Source: Olszewska A. A designing exercise in a course in Designing Landscape Architecture Facilities 2, Department of Green Space and Landscape Architecture, Poznań University of Life Sciences, 2013.

Widok pochylni przy różnicy wysokości terenu wynoszącej ok. 7 m. źródło: Olszewska A. Ćwiczenie projektowe z przedmiotu Projektowanie Obiektów Architektury Krajobrazu 2, KTZiAK UP Poznań, 2013

Fig. 7. A view of the ramp and stairs with diverse forms. Source: Szyc K. A designing exercise in a course in Designing Landscape Architecture Facilities 2, Department of Green Space and Landscape Architecture, Poznań University of Life Sciences, 2013.

Widok pochylni i schodów o zróżnicowanych formach. źródło: Szyc K. Ćwiczenie projektowe z przedmiotu Projektowanie Obiektów Architektury Krajobrazu 2, KTZiAK UP Poznań, 2013.

In order to match and inscribe ramp elements in the existing surroundings there are suggested solutions which make the rigid geometry of ramp projection and forms milder. This effect can be achieved by means of smoother lines, which better match the natural landscape, as can be seen in the designs in Figures 7, 8 and 9. The use of elements enriching and breaking the monotony of ramp forms is another designing procedure, whose aim is to match the ramp with its surroundings.

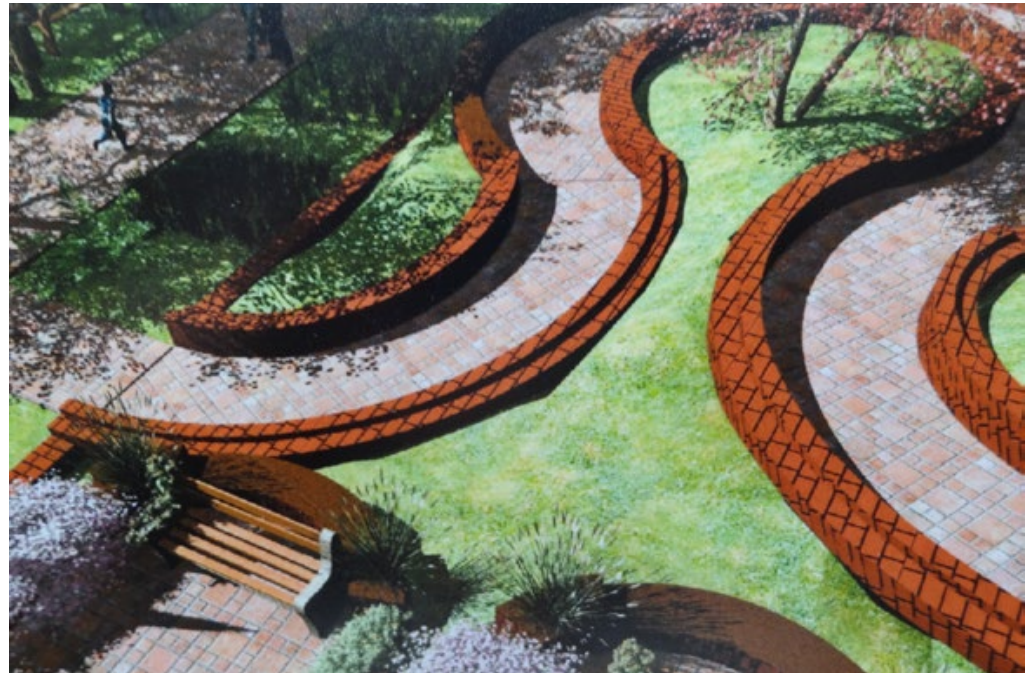

Fig. 8. A top view of the ramp with smooth lines. Source: Tomczak E. A designing exercise in a course in Designing Landscape Architecture Facilities 2, Department of Green Space and Landscape Architecture, Poznań University of Life Sciences, 2013.

Widok z góry na pochylnie zakomponowaną za pomocą linii płynnych. źródło: Tomczak E. Ćwiczenie projektowe z przedmiotu Projektowanie Obiektów Architektury Krajobrazu 2, KTZiAK UP Poznań, 2013. 


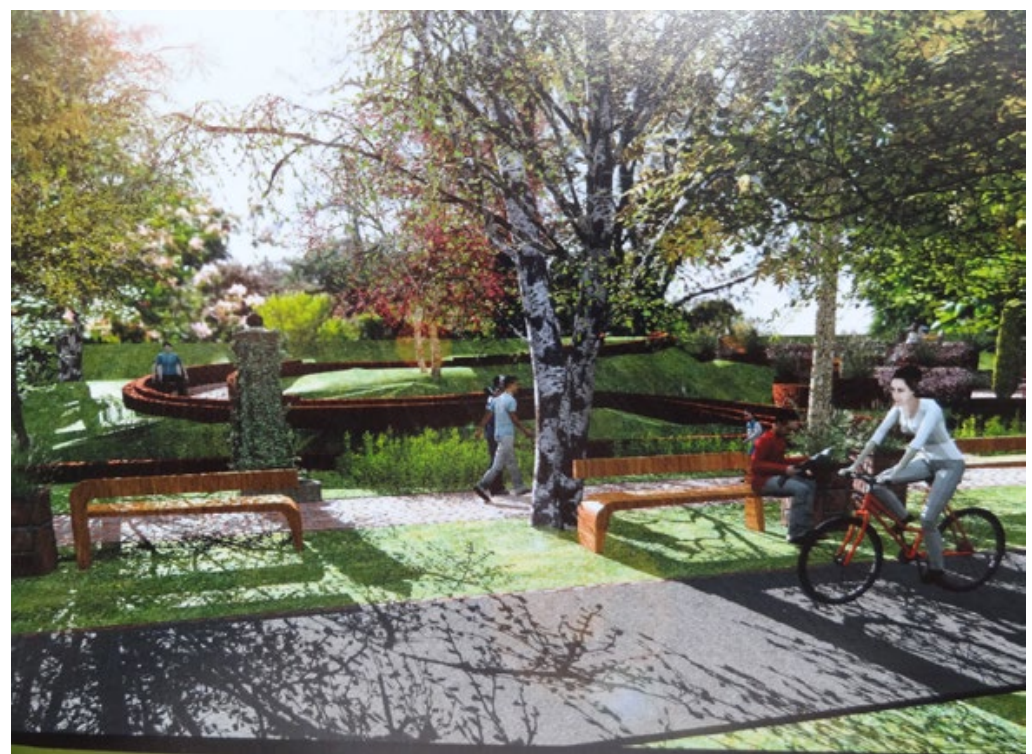

Fig. 9. View from the passer-by on ramps build using liquid line. source: Tomczak E. Exercise design of object Object Design Department of Green Space and Landscape Architecture, Poznań University of Life Sciences, 2013.

Widok na pochylnię zakomponowaną za pomocą linii płynnych, widziany przez przechodnia. źródło: Tomczak E. Ćwiczenie projektowe z przedmiotu Projektowanie Obiektów Architektury Krajobrazu 2, KTZiAK UP Poznań, 2013.

These elements include flower pots of different sizes and shapes with ornamental plants, small pools and watering holes as well as seats of different shapes and types. Ramps are also accompanied by stairs, which may also have diversified forms. The use of different materials to design ramps, stairs and accompanying elements has positive effect on the aesthetics and artistic character of a complex with these facilities. Appropriate terrain in the neighbourhood of a ramp may also positively link the ramp elements with the surroundings. The design of a ramp and stairs shown in Figure 7 is an example of application of these methods. This design uses different materials for individual flights of stairs and horizontal planes. Elements of the ramp are partly masked with an artificially shaped, undulating lawn. In the design in Figures 8 and 9 the projection of the ramp was formed with smooth lines. The shape of the horizontal projection was adjusted to the layout of trees in the design area so that the route of the ramp would run among the tree trunks and match the route of existing walkways. The final artistic expression of the designed complex of elements of landscape architecture was strongly influenced by colourful materials used to develop this space. The suggested colour scheme and structure of materials as well as newly planted ornamental vegetation create a characteristic artistic climate and match the space with the existing forms of tall vegetation with diversified colours.

\section{Summary}

Due to architectural barriers the situation of physically disabled people is still a social problem and very often an individual problem in Poland. A large number of spatial obstacles and the slow process of adjusting existing facilities and public spaces to disabled people's needs requires continuous education of society, especially future designers and decision-makers in charge of designing facilities, planning public space, green space and recreational areas as well as landscaping. Designs of these areas must meet the requirements of adequate knowledge, statutory regulations and branch standards. However, it is equally important that this environment should be created with due consideration of social, cultural, industrial, natural and utilitarian and aesthetic conditions. Introducing and maintaining appropriately high standards in material quality as well as spatial and landscape standards is one of regular tasks of science, mass media, creative communities and decision-makers, who are responsible for social education of future generations. 


\section{References}

[1] Bogalecki M. A designing exercise in a course in Designing Landscape Architecture Facilities 2, Department of Green Space and Landscape Architecture, Poznań University of Life Sciences, 2013.

[2] Olszewska A. A designing exercise in a course in Designing Landscape Architecture Facilities 2, Department of Green Space and Landscape Architecture, Poznań University of Life Sciences, 2013.

[3] Building Code - Building Code Act of 7 July 1994 (i.e. Official Journal 2013, Pos. 1490, Official Journal 2014, Pos. 40, 768, 822).

[4] Regulation of the Minister of Labour and Social Policy of 25 June 2002, specifying the type of tasks for a county which can be financed from the State Fund for Rehabilitation of Disabled Persons (Official Journal No. 96, Pos. 861 of 2002 with later alterations)

[5] Szyc K. A designing exercise in a course in Designing Landscape Architecture Facilities 2, Department of Green Space and Landscape Architecture, Poznań University of Life Sciences, 2013.

[6] Tomczak E. A designing exercise in a course in Designing Landscape Architecture Facilities 2, Department of Green Space and Landscape Architecture, Poznań University of Life Sciences, 2013.

[7] URL:http://www.pomozity.org/pl/aktualnosci/biuletyn-informacyjny/68-niepesnosprawnop-prawie- budowlanym.html (accessed on 10 October 2014).

[8] URL:http://www.pomozity.org/pl/aktualnosci/biuletyn-informacyjny/69-dofinansowanie-likwidacji-barier-arhitektonicznych.html (accessed on 10 October 2014).

\section{Niepełnosprawność a planowanie przestrzeni i krajobrazu - wybrane przykłady}

Streszczenie: W artykule przedstawiono zagadnienia związane z projektowaniem terenów rekreacji i zieleni oraz z planowaniem przestrzennym terenów publicznych w kontekście niepełnosprawności ruchowej. Zaprezentowano przykładowe propozycje zagospodarowania przestrzeni publicznych i stosowane tam rozwiązania przestrzenne służące osobom niepełnosprawnym. Omówiono również niektóre zagadnienia projektowe i realizacyjne związane z wybranymi obiektami architektury krajobrazu przeznaczonymi dla osób z niepełnosprawnością ruchową, które zastosowane w ramach edukacji architektów krajobrazu

Słowa kluczowe: niepełnosprawność ruchowa, bariery architektoniczne, planowanie przestrzeni publicznych, kształtowanie terenów zieleni 